\title{
Effects of yohimbine on novel open field exploration of mice
}

\author{
JOYCE M. RAWLEIGH, BRETT M. GIBSON, and ERNEST D. KEMBLE \\ University of Minnesota, Morris, Minnesota
}

\begin{abstract}
The effects of the anxiogenic compound yohimbine on exploration of a novel open field was investigated. The drug had no effect on latency to enter the open field but produced a marginally significant increase in number of open field entries. The results suggest that yohimbine may have behavioral stimulant and/or anticonflict properties under some testing conditions. Such effects may limit its usefulness as a research tool for the study of anxiety.
\end{abstract}

Although various forms of conspecific agonistic encounters (e.g., resident-intruder or isolation-induced aggression) provide clear evidence for the antiaggressive actions of drugs (see, e.g., Olivier, 1981), additional behavioral measures are needed to determine whether these effects are mediated by anxiolytic or anxiogenic properties. During previous investigations of the potent antiaggressive compound fluprazine, we (Kemble, Thornton, \& Schultz, 1987) found that drug treatment strongly inhibited entry into a novel open field, which presumably reflected a drug-induced anxiogenic effect. If this interpretation is correct, then this simple exploratory behavior might provide a convenient and sensitive tool for the detection of anxiogenic effects in other aggression-modulating drugs as well. In the present experiments, the effects of yohimbine on novel open field exploration were investigated. A substantial body of data demonstrate anxiogenic properties of yohimbine in a variety of test situations (see, e.g., Charney, Heninger, \& Redmond, 1983; Davis, Redmond, \& Baraban, 1979; File \& Johnson, 1987; Harris \& Newman, 1987; Tsuda, Ida, \& Tanaka, 1988). Drug treatment with yohimbine might therefore be expected to inhibit open field exploration as well.

\section{METHOD}

\section{Subjects}

The subjects were 24 experimentally naive male CD-1 mice weighing 30.0-49.2 $\mathrm{g}$ at the time of testing. All mice were individually housed for 8 days prior to testing with ad-lib access to Purina Lab Chow and water. The mice were randomly assigned to weight-balanced groups $(N=8)$, which received $0.5-\mathrm{mg} / \mathrm{kg}$ (low) or $2.0-\mathrm{mg} / \mathrm{kg}$ (high) dosages of yohimbine or an equivalent volume of isotonic saline (control). All drugs were administered by intraperitoneal injection.

\section{Apparatus and Procedure}

The apparatus and procedure were similar to those described previously (Kemble et al., 1987). Briefly, the mice were confined in a $15 \times 9 \times 9 \mathrm{~cm}$ lightproof startbox, which was constructed entirely of black

The authors would like to thank Sheldon Sparber, who kindly supplied the yohimbine used in this experiment. Please address correspondence to Ernest Kemble, Division of Social Sciences, University of Minnesota-Morris, Morris, MN 56267.
Plexiglas and had a $9 \times 9 \mathrm{~cm}$ guillotine door at one end. The startbox communicated with a $46 \times 36 \times 30 \mathrm{~cm}$ open field via a 5 -cm-diam opening. Two walls and the ceiling of the open field were of clear Plexiglas, while the remaining walls and floor were of flat gray plywood. The open field was brightly illuminated by a $170-\mathrm{W}$ incandescent bulb suspended $55 \mathrm{~cm}$ above the open field floor. Entrances into the open field were detected by a photocell placed $10 \mathrm{~cm}$ in front of the startbox door. Latencies were timed by an electronic timer with $.01-\mathrm{sec}$ accuracy. The observer and all programming equipment were located in an adjacent soundattenuating cubicle.

Immediately after drug or saline treatment, the mice were placed in the startbox. Thirty minutes later, the startbox door was opened, and latency to enter the open field and number of entries into the open field were recorded during a 10 -min test.

\section{RESULTS AND DISCUSSION}

Although the mean entrance latencies of both low $(M=37.7 \mathrm{sec})$ and high $(M=27.7 \mathrm{sec})$ yohimbinetreated groups were lower than control values $(M=$ $78.1 \mathrm{sec})$, the elevated control mean was due primarily to a single aberrant (318-sec latency) control mouse. Analysis of variance failed to suggest any reliable group differences $[F(2,21)=1.64, p>.10]$. Yohimbine treatment (low, $M=63.4$; high, $M=64.1$ ) did produce a marginally significant elevation $[F(2,21)=2.98, .10>p>.05]$ of open field entries over control $(M=40.5)$ levels, however.

In view of yohimbine's rather robust anxiogenic effects (see, e.g., Charney et al., 1983; Davis et al., 1979; Harris \& Newman, 1987; Tsuda et al., 1988), including suppression of maze exploration in rats (File \& Johnson, 1987), its failure to inhibit novel open field exploration was somewhat unexpected. It is possible, of course, that this relatively simple test is insensitive to the anxiogenic effects of some drugs. If so, however, it is difficult to understand why other simple responses such as social investigation (Guy \& Gardner, 1985) are not similarly affected by this drug. Alternatively, however, some investigators have reported that yohimbine increases nonreinforced (Huang, Messing, \& Sparber, 1987; Sanger, 1988) and even punished (Sepinwall \& Cook, 1981) leverpressing. The latter findings suggest that behavioral stimulant and/or anticonflict effects may override yohimbine's anxiogenic 
effects in some testing situations. The present results are consistent with such an interpretation and suggest that yohimbine may be of limited value as a research tool for the study of anxiety.

\section{REFERENCES}

Charney, D. S., Heninger, G. S., \& Redmond, D. E. (1983). Yohimbine induced anxiety and increased noradrenergic function in humans: Effects of diazepam and clonodine. Life Sciences, 33, 19-29.

Davis, M., Redmond, D. E., \& Baraban, J. M. (1979). Noradrenergic agonists and antagonists: Effects on conditioned fear as measured by the potentiated startle paradigm. Psychopharmacology, 65, 111-118.

FiLE, S. E., \& Johnson, A. L. (1987). Chronic treatment with imipramine does not reverse the effects of 3 anxiogenic compounds in a test of anxiety in the rat. Neuropsychobiology, 17, 187-192.

GuY, A. P., \& GARDNer, C. R. (1985). Pharmacological characterization of a modified social interaction model of anxiety in the rat. Neuropsychobiology, 13, 194-200.

HarRIs, J. C., \& Newman, J. D. (1987). Mediation of separation dis- tress by alpha ${ }_{2}$-adrenergic mechanisms in a non-human primate. Brain Research, 410, 353-356.

Huang, M., Messing, R. B., \& Sparber, S. B. (1987). Learning enhancement and behavioral arousal induced by yohimbine. Life Sciences, 41, 1083-1088.

Kemble, E. D., Thornton, A. E., \& Schultz, L. A. (1987). Some fear-potentiating effects of fluprazine hydrochloride in mice. Aggressive Behavior, 13, 269-280.

OLIVIER, B. (1981). Selective anti-aggressive properties of DU27725: Ethological analyses of intermale and territorial aggression in the male rat. Pharmacology, Biochemistry \& Behavior, 14, 61-77.

SANGER, D. J. (1988). Behavioral effects of the alpha ${ }_{2}$-adrenoceptor antagonists idazoxan and yohimbine in rats: Comparisons with amphetamine. Psychopharmacology, 96, 243-249.

SEPINWALL, J., \& COOK, L. (1981). Studies on clonodine in animal tests for antianxiety activity. Psychopharmacology Bulletin, 17, 24-26.

TsudA, A., IDA, Y., \& TANAKA, M. (1988). The contrasting effects of diazepam and yohimbine on conditioned defensive burying in rats. Psychobiology, 16, 213-217.

(Manuscript received March 7, 1990.) 